University of Nebraska - Lincoln

DigitalCommons@University of Nebraska - Lincoln

Summer 6-12-2013

\title{
Use and User's Satisfaction on Library Resources and Services in Tezpur University (India): a study
}

Mukesh Saikia

Librarian, Tezpur University

Anjan Gohain Mr

Tezpur University

Follow this and additional works at: https://digitalcommons.unl.edu/libphilprac

Part of the Library and Information Science Commons

Saikia, Mukesh and Gohain, Anjan Mr, "Use and User's Satisfaction on Library Resources and Services in Tezpur University (India): a study" (2013). Library Philosophy and Practice (e-journal). 972.

https://digitalcommons.unl.edu/libphilprac/972 


\title{
Use and User's Satisfaction on Library Resources and Services in Tezpur University (India): a study
}

\author{
Dr. Mukesh Saikia \\ Tezpur University \\ Email: mukesh@tezu.ernet.in
}

\author{
* Mr.Anjan Gohain \\ Tezpur University \\ Email: anjang@tezu.ernet.in
}

\begin{abstract}
This study is an investigation of use of library resources, user's satisfaction on library resources \& services and information seeking behaviors of the students and research scholars of Tezpur University. 200 questionnaires were distributed among students and research scholars of Tezpur University to collect relevant data. $79.5 \%$ (159) library users responded where $32.07 \%(51)$ respondents visited Central library, Tezpur University everyday for borrowing library books. It is found that 82.39\%(131) users borrowed text books,(79.87\%)(127) consulted journals and 75.47\%(120) read News papers to meet their information needs. Library is playing vital role to meet multidimensional demands of students, and research scholar for information and knowledge. It is felt that user guidance is necessary to help library users to meet their information needs and make users aware of the available library resources and services.
\end{abstract}

\section{Keywords}

Library Resources; Library Services; User behavior; Library collection; User's Satisfactions

\section{Introduction:}

Tezpur University was established in 1994. The University offers Doctor of Philosophy programme in 17 disciplines, Masters Degree programme in 20 disciplines, Post-Graduate Diploma in 3 disciplines, B. Tech. in 5 disciplines, Certificate programme in 1 discipline and integrated programme in 8 disciplines. The academic programmes have a distinct focus on Engineering Science \& Technology and Social Science \& Humanities, reflecting the objectives of the University. The Central Library, Tezpur University was established along with the establishment of the University. The library holds 53453 volumes of print documents and subscribed 906 titles of current journals (print 139, online 767) and three databases through INDEST - AICTE Consortium 
and other publishers. The UGC-Infonet of INFLIBNET Center and Delcon Consortium are providing access to 8000 e-journals and eleven databases. The library also holds more then $1800 \mathrm{CDs} / \mathrm{VCD}$ scattering to different thought contents. Library users can access book database, thesis database, journal database, ejournals and other e-resources from any terminal within the University campus. The Central library of the university regularly purchases good number of books, subscribes to a large number of print and electronic journals, and other reading materials to cater to the needs of the students, faculty members, research scholars and other staff members of this university.

\section{Statement of problem:}

A University library is a library attached with the University, have a very vital role to play to meet multidimensional demands for information and knowledge of students, teachers and research scholars. University library invests huge amount of money every years on the purchase, process and storage of information resources to serve its user. But changing information environment, application of ICT in library and availability of electronic information sources both in online and offline has made both library professionals and users confused to locate appropriate information as and when required. The study of information seeking behavior of library users has great impact on use of library resources and user's satisfaction. Student and research scholars of Tezpur University are most important segment of user communities. But no study is being done till today to know the use of library resources and users satisfaction on library resources \& services. It is the duty of the library professional to conduct periodic study of library users to know the users needs, satisfaction with library available resources \& services. Literature review reveals that there has been a good discussion on information seeking behavior in India. But comparatively little attention has been paid to study the use and users satisfaction on library resources and services at University system especially in North East India. Therefore, this study has been carried out at Central Library, Tezpur University to know the actual use of library resources, users need and user's satisfaction which will help to revise collection development policy and design new library services in digital era.

\section{Literature Review:}


Sahail and Upadhyay (2012) studied the use of library resources by the students of University of Kalyani. Authors found that guidance in the use of library resources and services was necessary to help students to meet their information needs. Authors also found that journals, text book and lecture notes were the most popular sources of information for the students. Authors suggested that the latest edition of text book and reference materials should be added to the library collection and users should be guided to use the resources of the library. Ranganathan and Babu (2012) studied the awareness and use of library resources and services at Osmania University, Hyderabad. Author studied that the adequacy of library resources, opinion on eresources or print sources, reasons for using e-resources, satisfaction on sources of information provision. Prabhavathi (2011) studied the information seeking behavior of post Graduate students of SPMV, Tirupoti to examine the information need, seeking behavior and availability of information resources that affects the information seeking pattern and communication process. Authors found that half of the respondents visited library everyday and main purpose of visiting the library was to prepare for examination. About $94.6 \%$ of respondents were using books to support their curriculum and examination. Author emphasized the need for orientation programme on library resources and services. Rahiman and Tamizhchelvan (2011) investigated the information need, use of information channels, information seeking process and information seeking behavior of the students of engineering colleges affiliated to Anna University. Authors also investigated the sufficiency of the library resources and the levels of satisfaction on library services. Kadle and Kumber (2011) investigated information seeking behavior of faculty in the changing ICT environment among the faculty members of 46 commerce colleges. The finding of the study revealed that majority of the faculty seeks information to prepare class note. It was also observed that information was scattered in too many sources and much information on Internet is the problems often faced by the users in information seeking. Changing ICT environment was also affected information seeking behavior for majority of users. Authors suggested that library should start information literacy programme to make users aware of library services. Tahira, Alias and Amen(2011) studied online information sources among science faculties of developing countries, trends and practices of science faculties to meet their information need. Siddiqui(2011)studied the information seeking behavior of B.Tech and M.Tech students to identify sources consulted and information gathering systems, and information seeking behavior. This study emphasized the importance of considering individual pattern of 
information seeking behavior of users. Mahajan(2009) studied the information seeking behaviour of undergraduate post graduate students and research scholars in Science, Social Sciences and Humanities at the Punjub University of India. The findings revealed that users were more or less satisfied with collection and services. Author further suggested that libraries must understand information seeking behaviour of users to provide information efficiently since methods and tools for information delivery continue to grow and changing dramatically

\section{Methodology:}

Keeping in view the objective of the study, a structure questionnaire was designed and distributed to collect the necessary primary data among the users visited to the library. The survey was conducted during Jan 2012 to Sep. 2012 .The population for this study consists of Bachelors Degree students, Master Degree students and Research Scholars of the University who frequently visited the library. Library users were also interviewed and statistical methods were applied to analysis collected data.

\section{Objective of the study:}

1. To investigate purpose of library visit

2. To study the use of library resources, facilities and services.

3. To determine the level of satisfaction of users towards library resources and services

4. To find out the type of information sources used by the students.

\section{Limitation:}

At present, there are 2413 numbers of registered library users. Out of these 1976 users are Bachelor degrees, Master degree student, Research. Scholars and other registered users are approximately 437. In order to make this study more accurate and specific, this survey was conducted among the Bachelor degree students, Master degree students and Research Scholars only instead of covering all categories of users. 


\section{Finding and analysis:}

Table I: Percentage of questionnaire responded

\begin{tabular}{clcc}
\hline Sl.No. & Respondents & $\begin{array}{c}\text { Questionnaire } \\
\text { Responded }\end{array}$ & Percentage \\
\hline 1 & Bachelor degree Student & 77 & 48.43 \\
\hline 2 & Master degree Student & 54 & 33.96 \\
\hline 3 & Research Scholar & 28 & 17.61 \\
\hline & Total & 159 & 100
\end{tabular}

\section{Percentage of Questionnair Responded}

\section{$\square$ Bachelor degree Student $\square$ Master degree Student $\square$ Research Scholar}

\section{Figure I: Percentage of questionnaire responded}

To collect relevant data total 200 questionnaire were prepared and served among the Bachelor Degree students, Master Degree Students and Research Scholars of Tezpur University. While distributing questionnaires attention was paid to ensure that bachelor degree student, master degree student and research scholars of various programmes were represented adequately in the population. Out of 200 questionnaires total $79.5 \%$ ( 159) respondents of targeted population responded to our questionnaire. Out of these, $48.43 \%($ 77) respond received from bachelor degree, $33.96 \%$ (54) and $17.61 \%$ (28) from master degree and research scholars respectively. 
Table II: School wise distribution of respondents

\begin{tabular}{clcc}
\hline SI.No & Respondents & Questionnaire & Percentage \\
& & responded & \\
& & 48 & 30.19 \\
\hline 1 & Engineering & 53 & 33.33 \\
\hline 2 & Humanities \& Social Science & 19 & 11.95 \\
\hline 4 & Business Administration & 39 & 24.53 \\
\hline 3 & Science & 159 & 100 \\
\hline & Total & & \\
& &
\end{tabular}

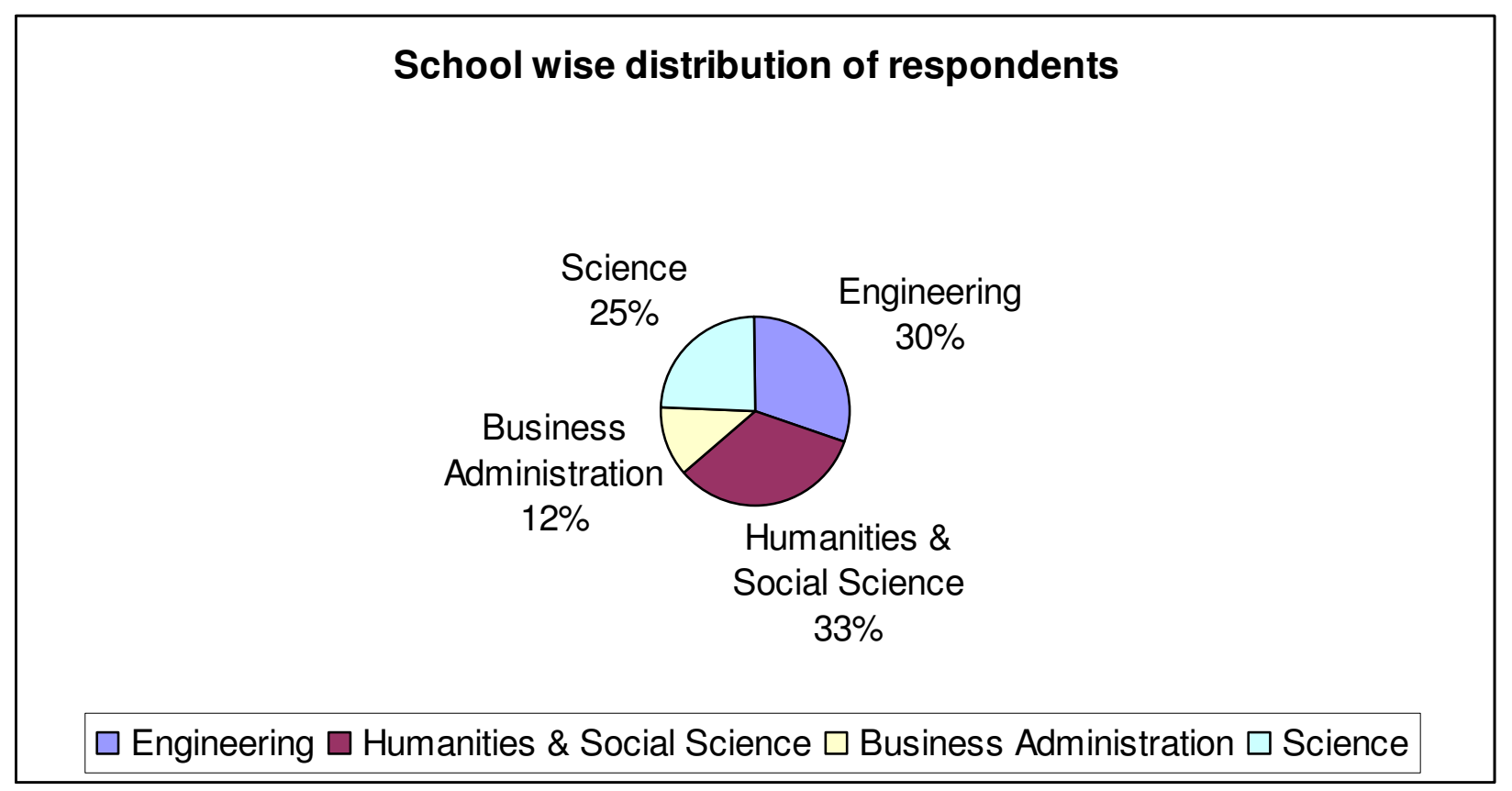

Figure II: School wise distribution of respondents

Table II \& Figure II shows the percentage of school wise distribution of respondents. It is to be mentioned that though questionnaire was distributed randomly, even than it shows that the response of School of Humanities and Social Science is largest in number responded with 33.33\%(53), followed by Schools of Engineering with $30.19 \%(48)$ respondents. The percentage of respondents of School of Business Administration was very negligible with $11.95 \%$ (19) responds than School of Science with $24.53 \%(39)$ respondents. 
Table III: Frequency of Visit Library

Sl.No. Frequency of Visit Library No. of Percentage

\section{Respondents}

\begin{tabular}{llcc}
\hline 1 & Every day & 51 & 32.07 \\
\hline 2 & $2-3$ times in a week & 63 & 39.62 \\
\hline 3 & Occasionally & 27 & 16.99 \\
\hline 4 & Don't use library & 18 & 11.32 \\
\hline & Total & 159 & 100
\end{tabular}

\section{Frequency of Visit Library}

Don't use library,

18

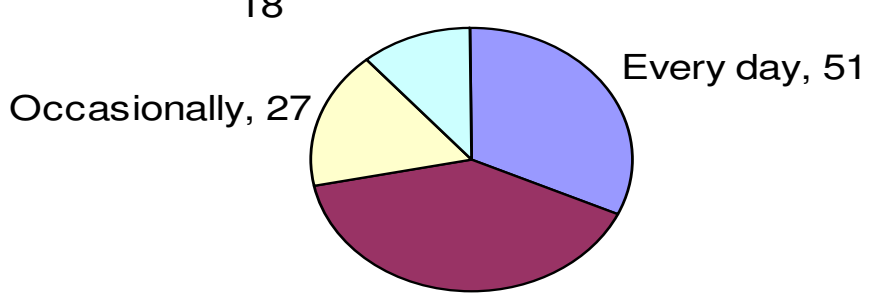

2-3 times in a week, 63

$\square$ Every day $\square$ 2-3 times in a week $\square$ Occasionally $\square$ Don't use library

Figure III: Frequency of Visit Library

Table III \& Figure III reveals that $32.07 \%(51)$ respondents have the habit to visit to the library everyday. $39.63 \%$ ( 63) students visit library two or three times in a week. Very few respondents $16.99 \%(27)$ indicated that they used to visit library occasionally. $11.32 \%$ ( 18) respondents mentioned that they don't use the library.

Table IV: Purpose of Visit Library

\begin{tabular}{llcc}
\hline Sl.No. & Purpose of Visit Library & No. of Respondents & Percentage \\
\hline 1 & Borrowing books & 42 & 26.41 \\
\hline 2 & Access Periodical & 31 & 19.50 \\
\hline 3 & Access Reference sources & 22 & 13.84 \\
\hline
\end{tabular}




\begin{tabular}{llcc}
\hline 4 & Access Back volume & 11 & 6.92 \\
\hline 5 & Read news paper and Magazine & 21 & 13.20 \\
\hline 6 & For general reading & 19 & 11.95 \\
\hline 7 & To know latest arrivals & 13 & 8.18 \\
\hline & Total & 159 & 100 \\
\hline
\end{tabular}

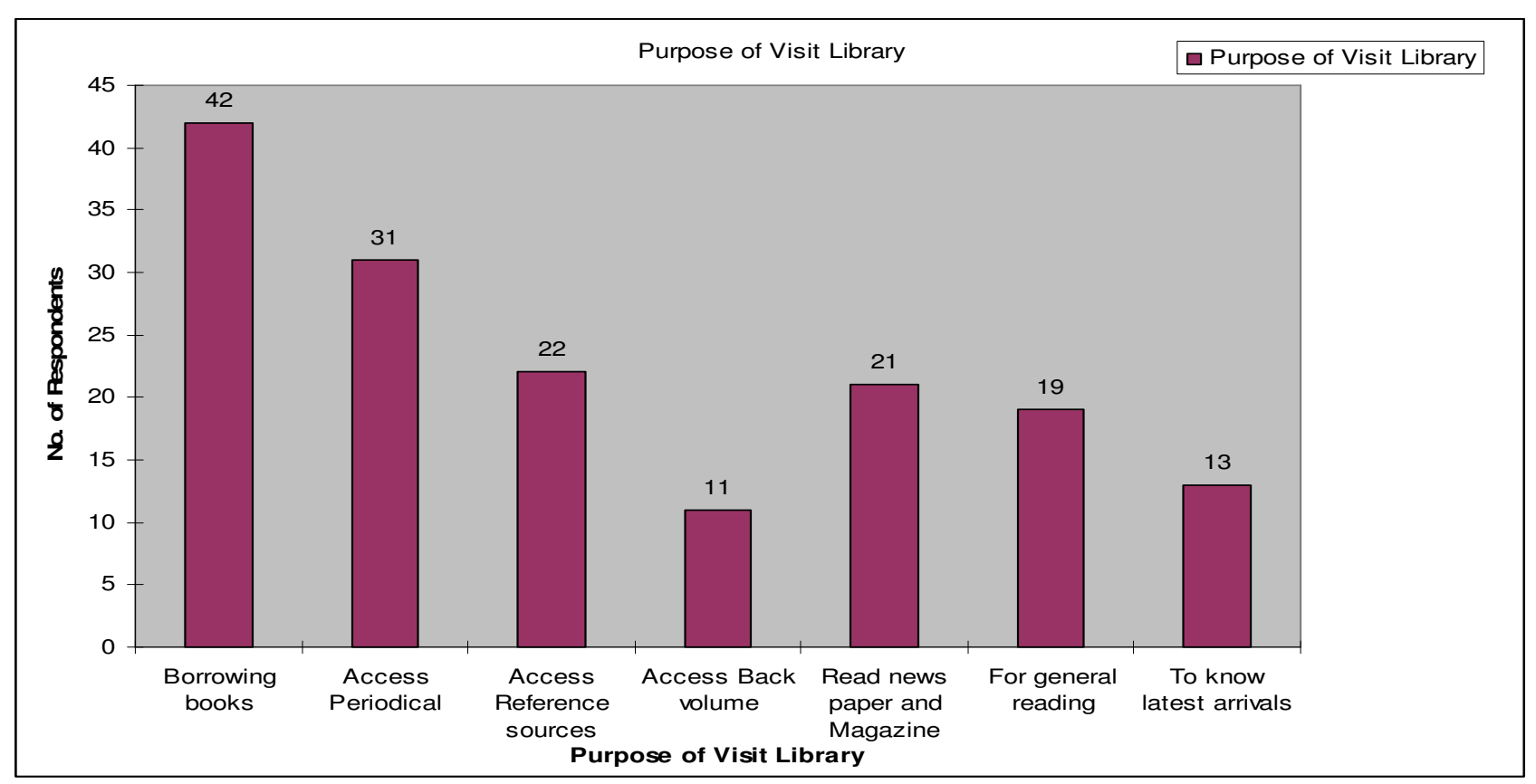

Figure IV: Purpose of Visit Library

Table IV \& Figure IV revealed that $26.41 \%$ ( 42) respondents visit library for the purpose of borrowing books, followed by access of periodicals which is $19.50 \%$ (31) of total respondents. $.13 .84 \%(22)$ of respondents visit library to access reference sources. In addition, $13.20 \%(21)$ and $11.95 \%$ ( 19) of respondents visit library to read News paper / Magazine and for general reading respectively. $6.92 \%$ ( 11) and $8.18 \%(13)$ respondents visit library to access back volume and to know about the latest arrivals respectively. From the above table it is observed that borrowing books is the main purpose of visiting library and followed by access to e-journals.

\section{Library Resources:}

Table: V: Use of Library Resources

\begin{tabular}{llllll}
\hline Sl. & Library Resources & Yes & No & No & Total \\
No. & & & Response & \\
\end{tabular}




\begin{tabular}{|c|c|c|c|c|c|}
\hline 1 & Text Book & $\begin{array}{l}131 \\
(82.39 \%)\end{array}$ & $\begin{array}{l}17 \\
(10.70 \%)\end{array}$ & $\begin{array}{l}11 \\
(6.91 \%)\end{array}$ & 159 \\
\hline 2 & Reference Sources & $\begin{array}{l}93 \\
(58.20 \%)\end{array}$ & $\begin{array}{l}27 \\
(16.98 \%)\end{array}$ & $\begin{array}{l}39 \\
(24.52 \%)\end{array}$ & 159 \\
\hline 3 & Back Vol. & $\begin{array}{l}83 \\
(52.20 \%)\end{array}$ & $\begin{array}{l}31 \\
(19.50 \%)\end{array}$ & $\begin{array}{l}45 \\
(28.30 \%)\end{array}$ & 159 \\
\hline 4 & Project/Thesis & $\begin{array}{l}58 \\
(36.48 \%)\end{array}$ & $\begin{array}{l}52 \\
(32.70 \%)\end{array}$ & $\begin{array}{l}49 \\
(30.82 \%)\end{array}$ & 159 \\
\hline 5 & Online Journals & $\begin{array}{l}127 \\
(79.87 \%)\end{array}$ & $\begin{array}{l}11 \\
(6.92 \%)\end{array}$ & $\begin{array}{l}21 \\
(13.21 \%)\end{array}$ & 159 \\
\hline 6 & News paper/Magazine & $\begin{array}{l}120 \\
(75.47 \%)\end{array}$ & $\begin{array}{l}18 \\
(11.32 \%)\end{array}$ & $\begin{array}{l}21 \\
(13.21 \%)\end{array}$ & 159 \\
\hline 7 & $\mathrm{CD} / \mathrm{DVD} / \mathrm{VCD}$ & $\begin{array}{l}39 \\
(24.53 \%)\end{array}$ & $\begin{array}{l}64 \\
(40.25 \%)\end{array}$ & $\begin{array}{l}56 \\
(35.22 \%)\end{array}$ & 159 \\
\hline
\end{tabular}

Table V \& Figure V shows the different types of resources used by the students and research scholars. It is observed in the table that maximum number of students users with $82.39 \%(131)$ used text book to meet their information needs, followed by the use of online journals with (79.87\%)127 and News paper with $75.47 \%(120)$ respondents. Out of seven library resources the responds of use of other resources was indicated as reference sources $58.20 \%$ (93); Back Vol. $52.20 \%$ ( 83) ;) Thesis/Project $36.48 \%$ ( 58) and 24.53\%( 39) of respondents used $\mathrm{CD} / \mathrm{DVD} / \mathrm{VCD}$ to meet their information need. It is clear from the table that the use of Back Vol., thesis and CD/DVD/VCD is very negligible in comparison to the books, online journals and News paper/Magazine.

Table: VI: Students Level of Satisfaction on Library Resources

\begin{tabular}{lllllll}
\hline Sl.No. & Library Resources & Highly & Satisfied & Not & No Response Total \\
& Satisfied & & Satisfied & \\
& & & & & \\
\hline & & & & & \\
& & & & & \\
& Text Book & $(37.74 \%)$ & $(44.65 \%)$ & $(14.47 \%)$ & $(3.14 \%)$ \\
\hline
\end{tabular}




\begin{tabular}{|c|c|c|c|c|c|c|}
\hline 2 & Reference Sources & $\begin{array}{l}49 \\
(30.82 \%)\end{array}$ & $\begin{array}{l}63 \\
(39.62 \%)\end{array}$ & $\begin{array}{l}34 \\
(21.38 \%)\end{array}$ & $\begin{array}{l}13 \\
(8.18 \%)\end{array}$ & 159 \\
\hline 3 & Back Vol. & $\begin{array}{l}51 \\
(32.08 \%)\end{array}$ & $\begin{array}{l}57 \\
(35.85 \%)\end{array}$ & $\begin{array}{l}49 \\
(30.82 \%)\end{array}$ & $\begin{array}{l}02 \\
(1.25 \%)\end{array}$ & 159 \\
\hline 4 & Project/Thesis & $\begin{array}{l}47 \\
(29.56 \%)\end{array}$ & $\begin{array}{l}31 \\
(19.49 \%)\end{array}$ & $\begin{array}{l}38 \\
(23.90 \%)\end{array}$ & $\begin{array}{l}43 \\
(27.04 \%)\end{array}$ & 159 \\
\hline 5 & Online Journals & $\begin{array}{l}63 \\
(39.62 \%)\end{array}$ & $\begin{array}{l}59 \\
(37.11 \%)\end{array}$ & $\begin{array}{l}27 \\
(16.99 \%)\end{array}$ & $\begin{array}{l}10 \\
(6.28 \%)\end{array}$ & 159 \\
\hline 6 & News paper/Magazine & $\begin{array}{l}56 \\
(35.22 \%)\end{array}$ & $\begin{array}{l}63 \\
(39.62 \%)\end{array}$ & $\begin{array}{l}30 \\
(18.87 \%)\end{array}$ & $\begin{array}{l}10 \\
(6.29 \%)\end{array}$ & 159 \\
\hline 7 & CD/DVD/VCD & $\begin{array}{l}39 \\
24.53 \%\end{array}$ & $\begin{array}{l}41 \\
25.79 \%\end{array}$ & $\begin{array}{l}48 \\
30.19\end{array}$ & $\begin{array}{l}31 \\
19.49\end{array}$ & 159 \\
\hline
\end{tabular}

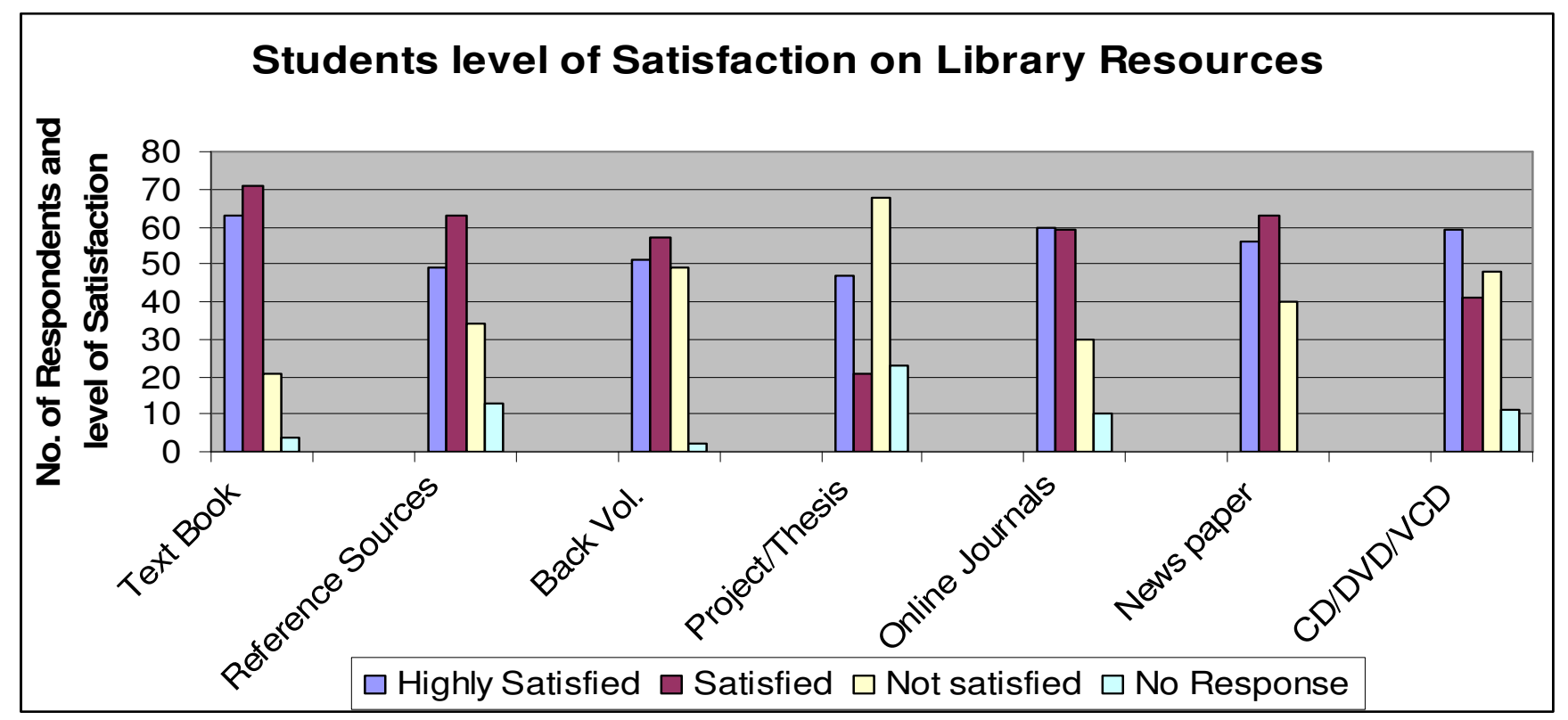

Figure VI: Students Level of Satisfaction on Library Resources

Table IV \& Figure VI revealed that $39.62 \%$ (63) respondents are highly satisfied with the collection of online journals, followed by collection of text books with $37.74 \%$ (60) of respondents. Out of seven library resources the level of satisfaction of other library resources was indicated as News paper/Magazine 35.22\%(56),Back Vol.32.08\%(51), Reference sources 30.82\%(49), thesis/project 29.56\%(47) and CD/DVD/VCD with $24.53 \%$ (39)of respondents. From the table it is also observed that respondent's first preference of satisfaction is online journals. This is followed by text books $37.74 \%(60)$, 
Newspaper/Magazine $35.22 \%$ ( 56) and Back Vol. $32.08 \%$ (51) of respondents. This table also shows that library should focus on adding more Back Vol. and CD/DVD/VCD and Reference Sources because most of the respondents feel that these resources are not sufficient and as per the user's expectations.

\section{Library Services:}

Academic library plays a vital role in teaching and learning of an academic institution. Its aims are to aims to collect, process, preserve and disseminate documents and information to serve the user community. In order to make the resources available to its user's easy and convenient way different types of facilities and services are being rendered from the Central Library, Tezpur University on a regular basis. Orientation programmes are organized in the library inviting new batch of students, research scholars, newly recruited faculty and staff member department wise. However, instructions on different techniques of accessing, browsing retrieving electronic resources is a regular activity in the library which is offered to the users when asked for as well as when the need is observed A website is also maintained for this purpose. Library online resources are available $24 \times 7$ on a $10 \mathrm{mbps}$ Internet speed. The library is open up to $10 \mathrm{pm}$ on weekdays. In order to accommodate more users, the library has extended its working hours from 9am to $12 \mathrm{pm}$ on weekdays; while it is $10 \mathrm{am}$ to $5 \mathrm{pm}$ on Saturdays and Sundays. The facilities and services offered to user in Tezpur University are as follows:

$>$ Circulation Service

$>$ OPAC Service/Web OPAC

Orientation Programe for fresher

E-Resource Retrieval Facility

Training \& demo on E-Resources retrieval

Content Page Alert service on Current Journals

Current Awareness Services of newly acquired books \& other resources

Reference/Information Service 
Reservation of Books Service

Reprographic Services (out sourced)

Mobile Alert Service

E-News Services

Book Bank facilities

Overnight issue

Table VII: Students Level of Satisfaction on Library Services

\begin{tabular}{llllllll}
\hline Sl.No & Services offered. & Excellent & Good & Fair & Need & Total \\
& & & & & improvement &
\end{tabular}

\begin{tabular}{|c|c|c|c|c|c|c|}
\hline 1 & Circulation Service & $\begin{array}{c}68 \\
(42.77 \%)\end{array}$ & $\begin{array}{c}71 \\
(44.65 \%)\end{array}$ & $\begin{array}{c}07 \\
(4.40 \%)\end{array}$ & $\begin{array}{c}13 \\
(8.18 \%)\end{array}$ & 159 \\
\hline 2 & OPAC Service/Web OPAC & $\begin{array}{c}53 \\
(33.33 \%)\end{array}$ & $\begin{array}{c}69 \\
(43.39 \%)\end{array}$ & $\begin{array}{c}11 \\
(6.93 \%)\end{array}$ & $\begin{array}{c}26 \\
(16.35 \%)\end{array}$ & 159 \\
\hline 3 & Orientation Programme for fresher & $\begin{array}{c}41 \\
(25.78 \%)\end{array}$ & $\begin{array}{c}69 \\
(43.40 \%)\end{array}$ & $\begin{array}{c}21 \\
(13.21 \%)\end{array}$ & $\begin{array}{c}28 \\
(17.61 \%)\end{array}$ & 159 \\
\hline 4 & E-Resource Retrieval Facility & $\begin{array}{c}44 \\
(27.67 \%)\end{array}$ & $\begin{array}{c}60 \\
(37.73 \%)\end{array}$ & $\begin{array}{c}31 \\
(19.50 \%)\end{array}$ & $\begin{array}{c}24 \\
(15.10 \%)\end{array}$ & 159 \\
\hline 5 & Training \& demo on E-Resources retrieval & $\begin{array}{c}47 \\
(29.56 \%)\end{array}$ & $\begin{array}{c}51 \\
(32.08 \%)\end{array}$ & $\begin{array}{c}28 \\
(17.61 \%)\end{array}$ & $\begin{array}{c}33 \\
(20.75 \%)\end{array}$ & 159 \\
\hline
\end{tabular}

\begin{tabular}{|c|c|c|c|c|c|c|}
\hline 6 & Content Page Alert service on Current Journals & $\begin{array}{c}48 \\
(30.19 \%)\end{array}$ & $\begin{array}{c}61 \\
(38.36 \%)\end{array}$ & $\begin{array}{c}21 \\
(13.21 \%)\end{array}$ & $\begin{array}{c}29 \\
(18.24 \%)\end{array}$ & 159 \\
\hline 7 & $\begin{array}{l}\text { Current Awareness Services of newly acquired } \\
\text { books }\end{array}$ & $\begin{array}{c}43 \\
(27.04 \%)\end{array}$ & $\begin{array}{c}59 \\
(37.11 \%)\end{array}$ & $\begin{array}{c}22 \\
(13.84 \%)\end{array}$ & $\begin{array}{c}35 \\
(22.01 \%)\end{array}$ & 159 \\
\hline 8 & Reference/Information Service & $\begin{array}{c}47 \\
(29.56 \%)\end{array}$ & $\begin{array}{c}55 \\
(34.61 \%)\end{array}$ & $\begin{array}{c}30 \\
(18.87 \%)\end{array}$ & $\begin{array}{c}27 \\
(16.96 \%)\end{array}$ & 159 \\
\hline 9 & Reservation of Books Service & $\begin{array}{c}62 \\
(38.99 \%)\end{array}$ & $\begin{array}{c}69 \\
(43.40 \%)\end{array}$ & $\begin{array}{c}09 \\
(5.66 \%)\end{array}$ & $\begin{array}{c}19 \\
(11.95 \%)\end{array}$ & 159 \\
\hline 10 & Online renewal & 58 & 62 & 29 & 10 & 159 \\
\hline
\end{tabular}




\begin{tabular}{|c|c|c|c|c|c|c|}
\hline & & $36.48 \%)$ & $(38.99 \%)$ & $(18.24 \%)$ & $(6.29 \%)$ & \\
\hline 11 & Reprographic Services (out sourced & $\begin{array}{c}51 \\
(32.07 \%)\end{array}$ & $\begin{array}{c}63 \\
(39.63 \%)\end{array}$ & $\begin{array}{c}37 \\
(23.27 \%)\end{array}$ & $\begin{array}{c}08 \\
(5.03 \%)\end{array}$ & 159 \\
\hline 12 & Mobile Alert Service & $\begin{array}{c}29 \\
(18.24 \%)\end{array}$ & $\begin{array}{c}38 \\
(23.90 \%)\end{array}$ & $\begin{array}{c}47 \\
(29.56 \%)\end{array}$ & $\begin{array}{c}45 \\
(28.30 \%)\end{array}$ & 159 \\
\hline 13 & E-News Services & $\begin{array}{c}43 \\
(27.04 \%)\end{array}$ & $\begin{array}{c}58 \\
(36.48 \%)\end{array}$ & $\begin{array}{c}17 \\
(10.69 \%)\end{array}$ & $\begin{array}{c}41 \\
(25.79 \%)\end{array}$ & 159 \\
\hline 14 & Book Bank facilities & $\begin{array}{c}28 \\
(17.61 \%\end{array}$ & $\begin{array}{c}37 \\
(23.27 \%)\end{array}$ & $\begin{array}{c}49 \\
(30.82 \%)\end{array}$ & $\begin{array}{c}45 \\
(28.30 \%)\end{array}$ & 159 \\
\hline 15 & Overnight issue & $\begin{array}{c}40 \\
(25.16 \%\end{array}$ & $\begin{array}{c}66 \\
(41.51 \%)\end{array}$ & $\begin{array}{c}37 \\
(23.27 \%)\end{array}$ & $\begin{array}{c}16 \\
(10.06 \%)\end{array}$ & 159 \\
\hline
\end{tabular}

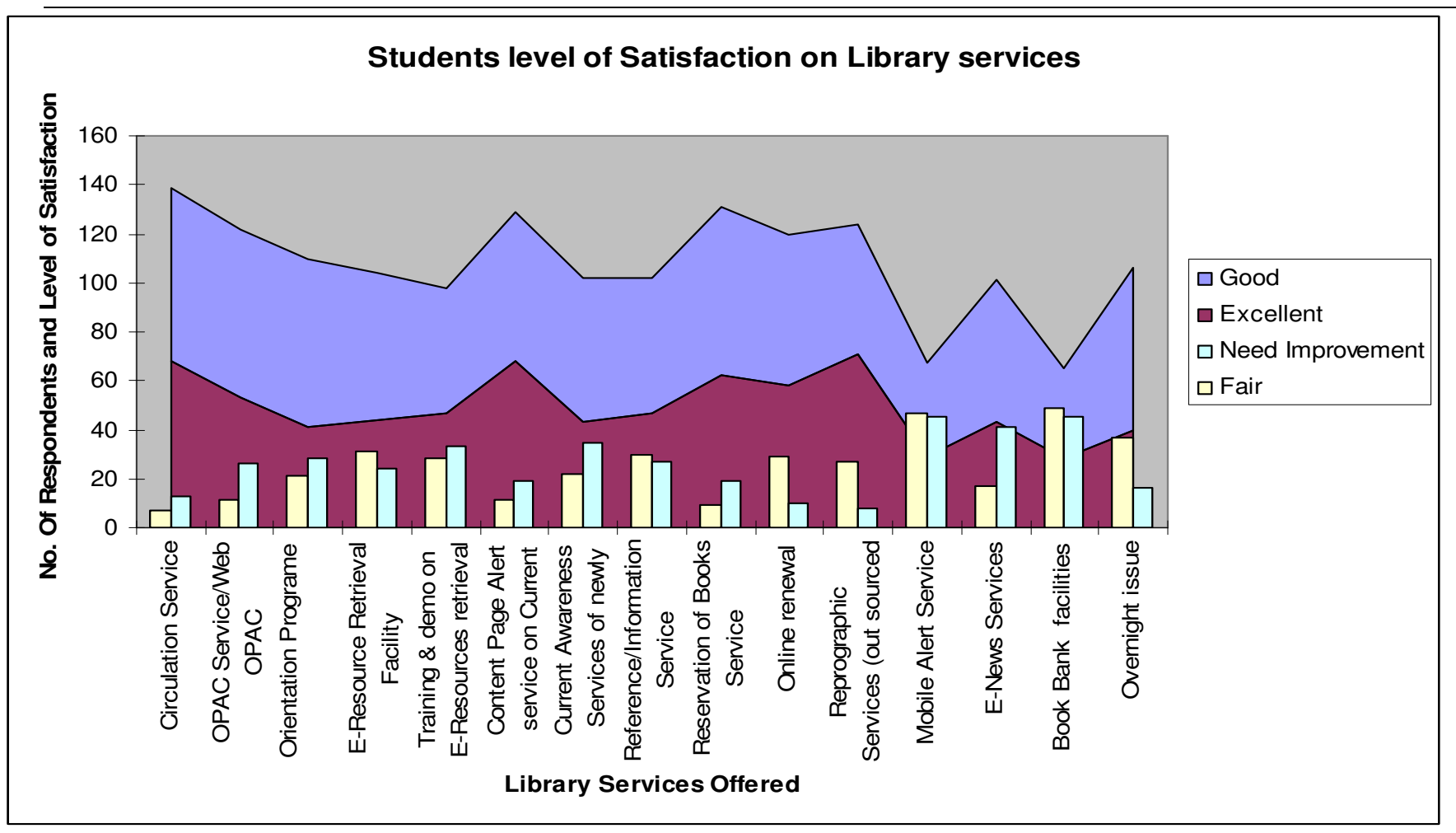

Figure VII: Students Level of Satisfaction on Library Services

The respondents were asked to give opinion on library facilities and services offered to them. The table VII \& Figure VII shows the level of satisfaction on facilities and services offered by library. It is observed in the table that $42.77 \%$ ( 68) of respondents consider the excellence on circulation services, followed by $38.99 \%($ 62) of respondents considered the reservation of book service as excellent. $36.48 \%$ ( 58) of respondents 
regarded online renewals of books service as excellent. This is followed by 33.33\%(53) OPAC/Web OPAC, 32.07\%(51) Reprographic services, 30.19\% (48) Content page alert services on current journals, 29.56\%(47) for training and demo on e-resource retrievals and reference and information services $.27 .67 \%(44)$ e- resource retrieval facilities, 27.04\%(43) e-News services, 25.78\%(41) for orientation programe and 18.24\%(29) Mobile alert service., Another finding reveals that $28.30 \%(45)$ respondents not satisfied with the performance of Mobile alert services and Book Bank facilities followed by $25.79 \%$ ( 41) e- news services, $20.75 \%(33)$ Training and demo on e-resource retrieval services, $22.01 \%$ ( 35) current awareness services of newly acquired books. So library should focus on these services in order to improve its performance.

\section{Summary of Finding:}

The findings of the survey are as follows:

$>$ Finding revealed that $39.63 \%$ (63) students visit library two or three times in a week. $32.07 \%(51)$ respondents have the habit to visit to the library everyday. Very few respondents $16.99 \%(27)$ indicated that they used to visit library occasionally.

$26.41 \%$ ( 42) respondents visit library for the purpose of borrowing books, $19.50 \%(31)$ respondents to access of periodicals. In this study it is observed that borrowing books is the main purpose of visiting library and followed by access to e-journals.

$82.39 \%(131)$ respondents used text book to meet their information needs , 79.87\%(127) respondents to access online journals with (79.87\%)127 followed by to read News paper with $75.47 \%(120)$ respondents. Out of seven library resources the responds of use of other resources was indicated as reference sources 58.20\%( 93); Back Vol. 52.20\%( 83) ;) Thesis/Project $36.48 \%$ ( 58) and 24.53 $\%$ ( 39) of respondents used CD/DVD/VCD to meet their information need.

Findings also revealed that $39.62 \%$ ( 63) respondents were highly satisfied with the collection of online journals, $37.74 \%$ (60) respondents with collection of text books. Out of seven library resources the level of satisfaction of other library resources was indicated as News paper/Magazine 35.22\%(56), Back Vol.32.08\%(51), Reference sources 30.82\%(49), thesis/project 29.56\%(47) and CD/DVD/VCD with $24.53 \%(39)$ of respondents. 
$>$ It is observed in the table that $42.77 \%$ (68) of respondents consider the excellence on circulation services. $38.99 \%$ ( 62) of respondents considered the reservation of book service as excellent. 36.48 $\%$ ( 58) of respondents regarded online renewals of books service as excellent. This is followed by $33.33 \%$ ( 53) OPAC/Web OPAC, $32.07 \%$ ( 51) reprographic services, 30.19\% (48) content page alert services on current journals, $29.56 \%$ (47) for training and demo on e-resource retrievals and reference and information services.

Another finding revealed that $28.30 \%(45)$ respondents not satisfied with the performance of Mobile alert services and Book Bank facilities followed by $25.79 \%$ ( 41) e- news services, $20.75 \%$ ( 33) Training and demo on e-resource retrieval services, $22.01 \%$ (35) current awareness services of newly acquired books. So library should focus on these services in order to improve its performance.

\section{Suggestion:}

On the basis of finding of the survey, following recommendations are made:

To develop effective user centered library and information services each University library must understand the information need of the users in order to address those needs. Library should conduct user studies at regular intervals, in order to know users information needs and their information seeking behaviors.

$>$ Librarian should develop an information marketing strategy to create awareness about library resources and services among students and research scholars. This will help better utilization of library resources and services offered in the library.

In order to fully exploit the available resources, and services, each library should conduct user awareness program at the beginning of each academic session. This will encourage more and more students and research scholars to use library resources and services.

User's first preference of choice is printed books. It is observed the lack of sufficient no of copies of book and non availability of latest edition is very common problem for users. It is recommended that latest edition of text book and reference materials should be added to the library collection regularly and users should be guided meticulously to use these resources. 
Library should subscribe more number of e -journals on different subject to meet the demand of the research scholars in their field of interest.

$>$ Infrastructure facilities should be enhanced for better utilization of e-resources and services in the each university library.

It is found that changing ICT environment has affected the information seeking behavior of users and library should initiate information literacy programme to make the users aware of available library resources and services.

$>$ Successful operation of any library depends to a large extent on the choice of library collection. The library collection should be according to the need requirement of all users.

Library staff should be properly trained so that they may have better understanding about how to search, downloaded needed information from e- resources. This staff ultimately can help the users to explore available- resources exhaustively and can also motivate the user to use e- resources independently.

Another finding revealed that respondents not satisfied with the quality and performance of Mobile alert services, Book Bank facilities, Training and demo on e-resource retrieval services, , current awareness services of newly acquired books and with e- news services . So library should focus on these services in order to improve its quality and performance.

\section{Conclusion:}

University library invest cores of rupees every year on the collection development in order to meet the need of users. In order to maximize the use of library resources, every library should build up their collection keeping in mind the need of users and should design library with changing information environment. This study revealed that nearly half of the total respondents visit library regularly and borrowing books is the main purpose of visiting library, followed by reading print journals \& access to online periodicals, reference sources and to read News paper/Magazine. This study revealed that printed books are still occupying a predominate place in library to meet students information needs. Tezpur University subscribed 906 titles of current journals (print 139, online 767) and three databases through INDEST - AICTE Consortium and other 
publishers. The UGC-Infonet Consortia of INFLIBNET Center is providing access to 7500 e-journals and eleven databases. The study revealed that students and research scholars are highly satisfied with the collection of online journals and use these online journals both for academic and research purpose. ICT application in library services is also providing opportunities to users to access and utilize both library online resources and services effectively. Respondents are very much satisfied with the performance circulation, online reservation and online renewal of book services offered by the library. A University library has a very vital role to play to meet multidimensional demands. University library should build digital library of thesis/ dissertation to support research activities of the research scholars.

\section{References}

1. Sohil MD, Pandye A, Upadhyay Ak (2012). Use of library resources in university libraries by students: a survey with special reference the University of Kalian. IASIC Bulletine., 57(2):122-128.

2. Prabhavathi D (2011). Information seeking behaviour of post graduate students of SPMW , Tirupati (A.P): a study . International Journal of Digital Library Service.. 1(1):34-47.

3. Mahajan P (2009). Information seeking behavior: a study of Punjub University, India. Library Philosophy and Practice(e-journals) (March):1-6.

4. Rahiman S A F ,Tamizhchelven M (2011).Information seeking behavior of students of engineering college in and around Coimbatore : a study. European Journal of Scientific Research. ,61(2) : 265-72.

5. Ranganathan S , Babu KS (2012).Awareness and use of library information resources and services in Osmania University, Hydrabad. International Journal of Library and Information Studies.,2 (3): 42-54.

6. Tahira M , Alias RA, Ameen K (2011).Seeking online information sources among science faculties of developing countries. Library Philosophy and practice(e-journals).

7. Kadli J , Kumbar BD (2011).Faculty information seeking behaviour in changing ICT environment: A study of commerce colleges in Mumbai. Library Philosophy and Practice (e-journals).

8. Siddique S (2011).Information seeking behaviour of B.Tech and M.B.B.S students in Lucknow: a comparative study. International research: Journal of Library and Information Science., (1):55-69. 


\section{About Authors:}

*Dr. Mukesh Saikia

* Mr.Anjan Gohain

Librarian, Central Library

Tezpur University,Assam

Professional Assistant, Central Library

Tezpur University ,Assam.

Email: mukesh@tezu.ernet.in

Email: anjang@tezu.ernet.in 